\title{
New data on the provenance of copper finds from the Early-Middle Copper Age of the Great Hungarian Plain
}

\author{
Zsuzsanna Siklósi ${ }^{1}$ (D) Márton Szilágyi ${ }^{1,2}$
}

Received: 22 September 2018 / Accepted: 13 May 2019 / Published online: 15 June 2019

(C) The Author(s) 2019

\begin{abstract}
The completely excavated settlement and cemetery of Rákóczifalva-Bivaly-tó Site 1/C provide a unique opportunity to study the copper artefacts and the question of local metallurgy on the Great Hungarian Plain in the Early-Middle Copper Age (4350$4000 \mathrm{cal} \mathrm{BC}$ ). Although the cemetery is rich in metal finds, no traces of local metallurgy were found in the settlement. The results of chemical compositional analysis revealed that the copper finds were made of pure copper; their compositions were very similar to each other, except for two daggers which contained a higher amount of arsenic and silver. The lead isotope analysis (LIA) suggested that the raw material of axes and spiral bracelets likely derives from the Balkans, most probably from Majdanpek and from the present-day Central Bulgaria. Furthermore, a currently unknown source has to be taken into consideration in the case of a large bracelet. The majority of copper finds in the cemetery occurred together with Bodrogkeresztúr-style pottery, and these may be contemporary with the Krivodol-Sălcuța-Bubanj Hum complex. This points to the fact that the Great Hungarian Plain belonged to the Central Balkan copper supply network.
\end{abstract}

Keywords Copper $\cdot$ Copper Age $\cdot$ Chemical compositional analysis $\cdot$ Lead isotope analysis (LIA)

\section{Introduction}

The heavy copper axes found in the Carpathian Basin, primarily on the Great Hungarian Plain, caught the researchers' attention in the nineteenth century. Based on these metals, Pulszky argued for the existence of an independent Copper Age in the Carpathian Basin (Pulszky 1884). This independent chronological period was related to several significant cultural, socioeconomic changes and innovations (e.g. secondary products, formal cemeteries, metallurgy) in Southeast Europe and the Carpathian Basin (Lichardus 1991; Schier 2014). However, considerable regional differences can be

Zsuzsanna Siklósi

siklosi.zsuzsanna@btk.elte.hu

Márton Szilágyi

szilagyi.marton84@gmail.com

1 Institute of Archaeological Sciences, ELTE Eötvös Loránd University, Múzeum körút 4/B., Budapest H-1088, Hungary

2 Institut für Vor- und Frühgeschichtliche Archäologie, Universität Hamburg, Edmund-Siemers-Allee 1, West,

20146 Hamburg, Germany found. Among them, this article focuses on copper finds on the Great Hungarian Plain.

Although the appearance of these spectacular axes can be linked to the Copper Age, the beginning of metallurgy can be traced back to the Neolithic. In the Early Neolithic (6000$5500 \mathrm{cal} \mathrm{BC}$ ), tiny beads and small items made of native copper were produced sporadically, using the technology of stone processing. Moreover, copper was also used as a pigment (Kalicz's Horizon 1a, Strahm/Hauptmann's preliminary stage) (Kalicz 1992; Strahm and Hauptmann 2009). This period was a time of experimentation. Although local raw material sources were already known in the Balkans, purposeful, systematic metallurgy did not exist yet (Horedt 1976; Jovanović and Ottaway 1976; Chapman and Tylecote 1983; Comşa 1991; Gale et al. 1991; Antonović 2002). The beginnings of extractive metallurgy can be dated to the Middle Neolithic (5500-5000 cal BC) in the Balkans. From this time, the use of copper mines was proven by archaeological excavations, and small artefacts and ornaments were produced. During the Late Neolithic (5000-4500 cal BC), copper axes were manufactured from local raw materials in the Balkans (Kalicz's Horizon 1b, Strahm/Hauptmann's initial phase) (Jovanović 1971; Chernykh 1978a; Jovanović 1982, 1983; Kalicz 1992; Šljivar 1996, 2006; Šljivar et al. 2006; Borić 2009; Strahm and Hauptmann 2009; Radivojević et al. 
2010; Antonović 2016). Metallurgy in the Balkans reached such a scale for the first time in this period that its products could be spread to further areas, such as the Great Hungarian Plain (Siklósi et al. 2015).

Kalicz's Horizon 2 (Strahm/Hauptmann's innovation phase) was characterised by the first appearance of heavy copper tools (hammer axes) and an abrupt increase in the number of copper items during the Early Copper Age Tiszapolgár culture (4550/4500-4000 cal BC) (Kalicz 1992; Strahm and Hauptmann 2009). Hammer axes were found in the graves of the Early Copper Age cemeteries in Tibava and Vel'ké Raškovce (Šiška 1964; Novotná 1970; Vizdal 1977). However, from other, well-dated, properly documented Tiszapolgár contexts on the Great Hungarian Plain, only small copper tools (pins, awls) and ornaments (such as beads, rings and bracelets) have been recorded (Bognár-Kutzián 1963, 1972). Based on the geographical concentration of these finds, Kalicz considered them as the products of the Southeast European metallurgy (Kalicz 1992). Several scholars argued that the scale of metallurgy led to social inequality in this period (Renfrew 1978, 1986; Lichardus 1991; Strahm and Hauptmann 2009). Kalicz's Horizon 3, the Bodrogkeresztúr period, was considered to be an organic continuation of the previous Horizon 2 (Kalicz 1992). This period was formerly dated to 4000-3600 cal BC, but recent Bayesian modelled AMS dates revealed that the Bodrogkeresztúr find material can be dated to $4350-4000$ cal BC (Raczky and Siklósi 2013; Siklósi and Szilágyi 2016). The time of this culture is generally considered to be the peak of Copper Age metallurgy in the Carpathian Basin, primarily based on the distribution of heavy copper shaft-hole axes (axe-adzes) and gold ornaments (Kalicz 1992; Strahm and Hauptmann 2009). The first clear evidence for local copper production on the Great Hungarian Plain can be found at the end of this period (Patay 2005) recently dated to 3900-3700 cal BC (Raczky and Siklósi 2013) - which was followed by a sudden, major decline in copper metallurgy during the Baden complex period (36002900 cal BC; Kalicz's Horizon 4). This was frequently explained by the exhaustion of available raw material sources (Kalicz 1992; Powell et al. 2017) but this issue is still severely disputed (Jansen 2018; Powell et al. 2018).

As was already highlighted in the 1960s by BognárKutzián, potential, local raw material sources of copper metallurgy are absent from the Great Hungarian Plain (BognárKutzián 1963). Based on the huge amount of heavy copper tools on the Plain, several scholars believed that local metallurgy existed and considered the territory of Bodrogkeresztúr culture and the Carpathian Basin as the centre of production (Kalicz 1992; Pernicka et al. 1997; Strahm and Hauptmann 2009). These models, based on the distribution of copper artefacts, frequently confused the place of production with the location of the final use or deposition of the artefacts. Furthermore, it is a serious methodological problem that the majority of these finds stem from an unknown find context (Patay 1984), as is the case with the majority of contemporary copper artefacts from Serbia (Antonović 2014). Contrary to this, most Copper Age copper artefacts were found during excavations in Bulgaria (Todorova 1981; Pernicka et al. 1997). Based on the find from Polgár-Basatanya grave 59 (which is a still unspecified ingot or semi-finished product) and the hoard of Szeged-Szillér, Bognár-Kutzián assumed that copper artefacts were prepared using semi-finished products in local settlements, from at least the Middle Copper Age. She believed that at least the final hammering may have taken place on the Great Hungarian Plain (Bognár-Kutzián 1963).

In spite of the huge number of copper finds on the Great Hungarian Plain, only a few have a well-known, scientifically documented archaeological context, and even fewer are dated precisely by AMS measurements.

Patay et al. (1963) published the first results of archaeometallurgical analyses carried out on Early and Middle Copper Age copper artefacts in Hungary, then several further artefacts were analysed in the frame of the SAM project (Junghans et al. 1960, 1968). Despite the large amount of Copper Age copper items and the significance of the region, until now, no lead isotope analysis (LIA), which could identify the origins of copper raw material, has been performed in Hungary. This study publishes the first such results. The origin of copper raw material can be best identified by studying the combination of lead isotope along with chemical compositional analyses. This helps to exclude certain raw material resources (Radivojević et al. 2010; Pernicka 2014).

\section{Materials and methods}

\section{Materials}

\section{Early and Middle Copper Age on the Great Hungarian Plain}

Considerable changes took place at the end of the Neolithic, around 4550-4500 cal BC. After the cessation of Late Neolithic tells on the Great Hungarian Plain, information about the Early and Middle Copper Age mainly derived from cemeteries; contemporary settlements were hardly known (Bognár-Kutzián 1972; Patay 1974). These Copper Age societies were therefore considered primarily mobile pastoral economies (Sherratt 1984; Bökönyi 1988). However, recently performed strontium isotope analyses have modified this assumption crucially (Giblin et al. 2013). Diet did not change considerably at the beginning of the Copper Age, and the consumption of dairy products did not increase significantly (Hoekman-Sites and Giblin 2012; Giblin and Yerkes 2016). At the beginning of the Copper Age, the settlement system had been transformed, and it consisted of small-scale, independent hamlets. The location of settlements changed more 
frequently (Parkinson 2006; Giblin and Yerkes 2016). For the first time in the history of this region, formal cemeteries emerged around 4350 cal BC (Raczky and Siklósi 2013; Siklósi and Szilágyi 2016). While these transformations were happening, the material culture also changed, and the find material called Tiszapolgár culture came into existence (Bognár-Kutzián 1963, 1972). At the same time, several elements of the material culture and mortuary practice were maintained (Raczky et al. 2014). Thus, these changes have recently been interpreted as complex, internal sociocultural transformations (Parkinson 2006). The material culture, primarily the pottery style, became more homogenous, and in addition to the copper ornaments, heavy copper tools and gold ornaments also appeared around $4350 \mathrm{cal}$ BC (Raczky and Siklósi 2013; Siklósi and Szilágyi 2016). Partially contemporarily with these processes, the Bodrogkeresztúr culture also emerged. It was essentially characterised by the special form of milk jugs and primarily known from cemeteries (Patay 1974). Burial rites were mainly determined by the age, gender and personal achievements of individuals (Bognár-Kutzián 1963; Meisenheimer 1989; Sofaer Derevenski 1997; Lichter 2001). The number of settlements characterised by Bodrogkeresztúr-style pottery is still low (Sherratt 1983; Parkinson 2006; Gyucha 2015). Moreover, the question emerges that the Bodrogkeresztúr find material might have been primarily used in the ritual context of cemeteries and wells (Szilágyi 2015).

This study focuses on a unique site complex which consists of a completely excavated settlement and a neighbouring completely excavated cemetery. Although few general conclusions about the Great Hungarian Plain can be drawn from this case study, this is the first opportunity to study the role of metal finds of both Early and Middle Copper Age cemeteries and settlements from an archaeometallurgical point of view.

\section{The archaeological context-Rákóczifalva-Bivaly-tó Site 1/C}

Between 2005 and 2007, a Copper Age cemetery consisting of 79 graves was fully revealed during the preventive excavations prior to the regulation of the Tisza river's flood area (Fig. 1) (Csányi et al. 2010). A dividing 120-140-m-wide empty area separates the cemetery from the fully unearthed contemporary settlement (Fig. 2).

The settlement consists of two buildings surrounded by pits. A further burial was found in one of them (Csányi et al. 2010; Szilágyi 2015). The graves in the cemetery formed two grave groups in which the graves were organised into approximately SW-NE-oriented lines; the burials themselves were oriented towards SE-NW. Mortuary practice is identical with the rite observed in several contemporary cemeteries on the Great Hungarian Plain (Bognár-Kutzián 1972; Patay 1974). Men were usually laid on their right, and women on their left sides in a crouched position. Grave goods were mostly vessels, food, ornaments and tools (made of stone, copper and gold). Four cenotaphs were also found in the cemetery (Csányi et al. 2010).

According to the available AMS dates (Csányi et al. 2010), the two grave groups can also be distinguished chronologically. The radiocarbon dates were calibrated with the IntCal13 curve (Reimer et al. 2013) and using the OxCal 4.2.4 software (Bronk Ramsey 2009). The use of the western group may have begun in $4350(68.2 \%) 4265 \mathrm{cal} \mathrm{BC}$ and was used until $4305(68.2 \%) 4225 \mathrm{cal} \mathrm{BC}$, so its span was very short, at most 50 years. The eastern grave group yielded slightly younger dates. It started in $4250(68.2 \%) 4110 \mathrm{cal} \mathrm{BC}$ and was used

Fig. 1 Location of the site in Hungary

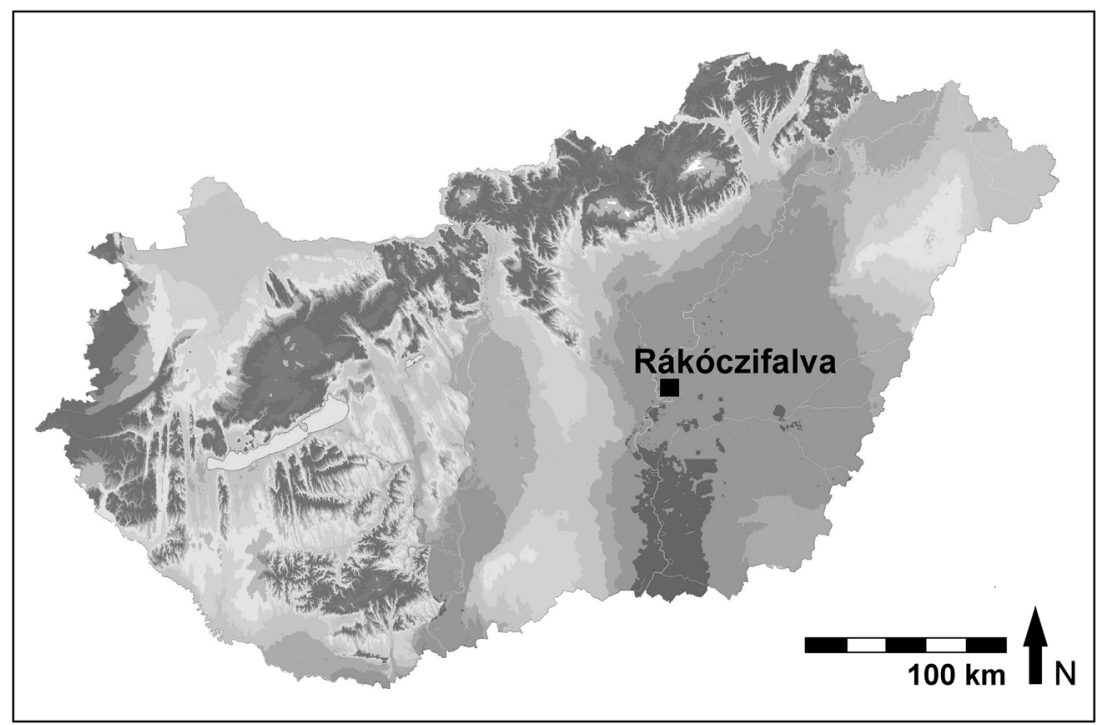


Fig. 2 Map of RákóczifalvaBivaly-tó Site $1 / \mathrm{C}$

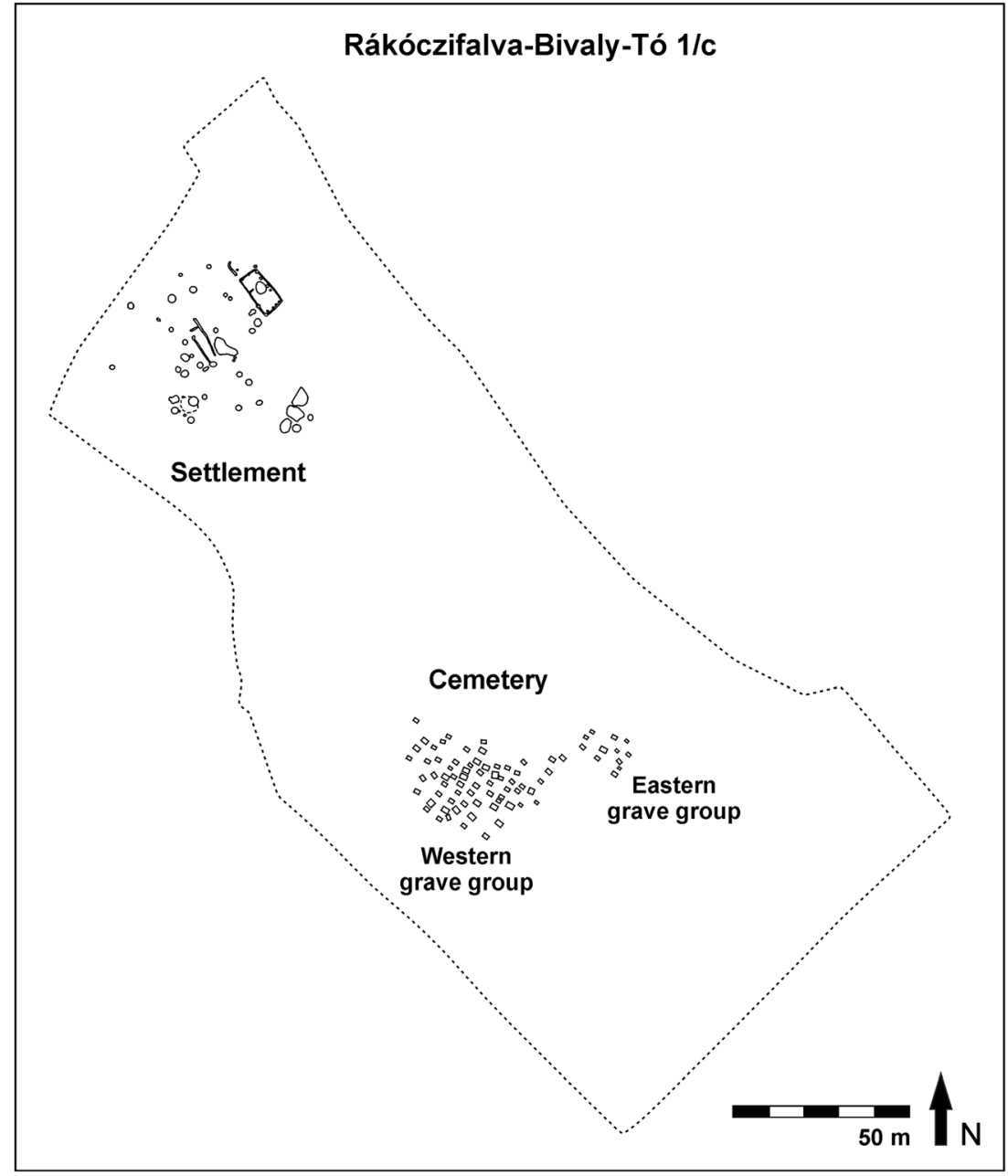

until $4155(68.2 \%) 4015 \mathrm{cal} \mathrm{BC}$ which represents at most 80 years (Fig. 3 ).

Two axes were found in the cemetery. A Şiria-type hammer axe and a golden cone were placed into the grave of a 34-38year-old man and a Jászladány-type axe-adze was discovered in a cenotaph (Csányi et al. 2010). Both graves contained Bodrogkeresztúr-style pottery. The cenotaph is situated in the centre of the cemetery, surrounded by an empty area. Taking all other grave goods into consideration (milk jugs, long Volhynian flint blades, a large spearhead, a boar mandible), this grave may have been a symbolic representation of relations forming social identity with considerable importance for the community.

A heavy, open-ended copper bracelet was found around the right forearm of a 26-30-year-old man whose grave contained Tiszapolgár-style vessels. Small pins or awls were found only in adult male graves. Burials of adult men accompanied by daggers and Bodrogkeresztúr-style pottery were concentrated in the eastern, younger grave group (Csányi et al. 2010).

Tiny beads were also found in the graves of children and adult females. Only one grave, that of an adult woman, contained both copper and gold ornaments accompanied by Bodrogkeresztúr-style pottery. There were multiple spiral bracelets on both of her wrists and gold pendants on her temples. Three more female burials contained golden pendants, but no further metal ornaments (Csányi et al. 2010).

In contrast with the 18 copper artefacts and further gold ornaments found in the burials (Csányi et al. 2010), neither metal artefacts nor finds referring to metallurgy were revealed in the settlement.

\section{Methods}

We started the archaeometallurgical analysis of copper finds in 2008, when 8 copper finds were sampled. The samples of 10 and $150 \mathrm{mg}$ of weight were taken by drilling with a $1.5-\mathrm{mm}$ stainless steel drill (DIN 338, type VA) following the sampling protocol of the Deutsches Bergbau Museum, Bochum. This drill causes no significant contamination of the sample material.

The amounts of the main, minor and trace elements were determined by an inductively coupled plasma- 
Fig. 3 Probability distributions of radiocarbon dates from the Copper Age cemetery at Rákóczifalva-Bivaly-tó Site 1/C. The square brackets down the left-hand side along with the OxCal keywords exactly define the model

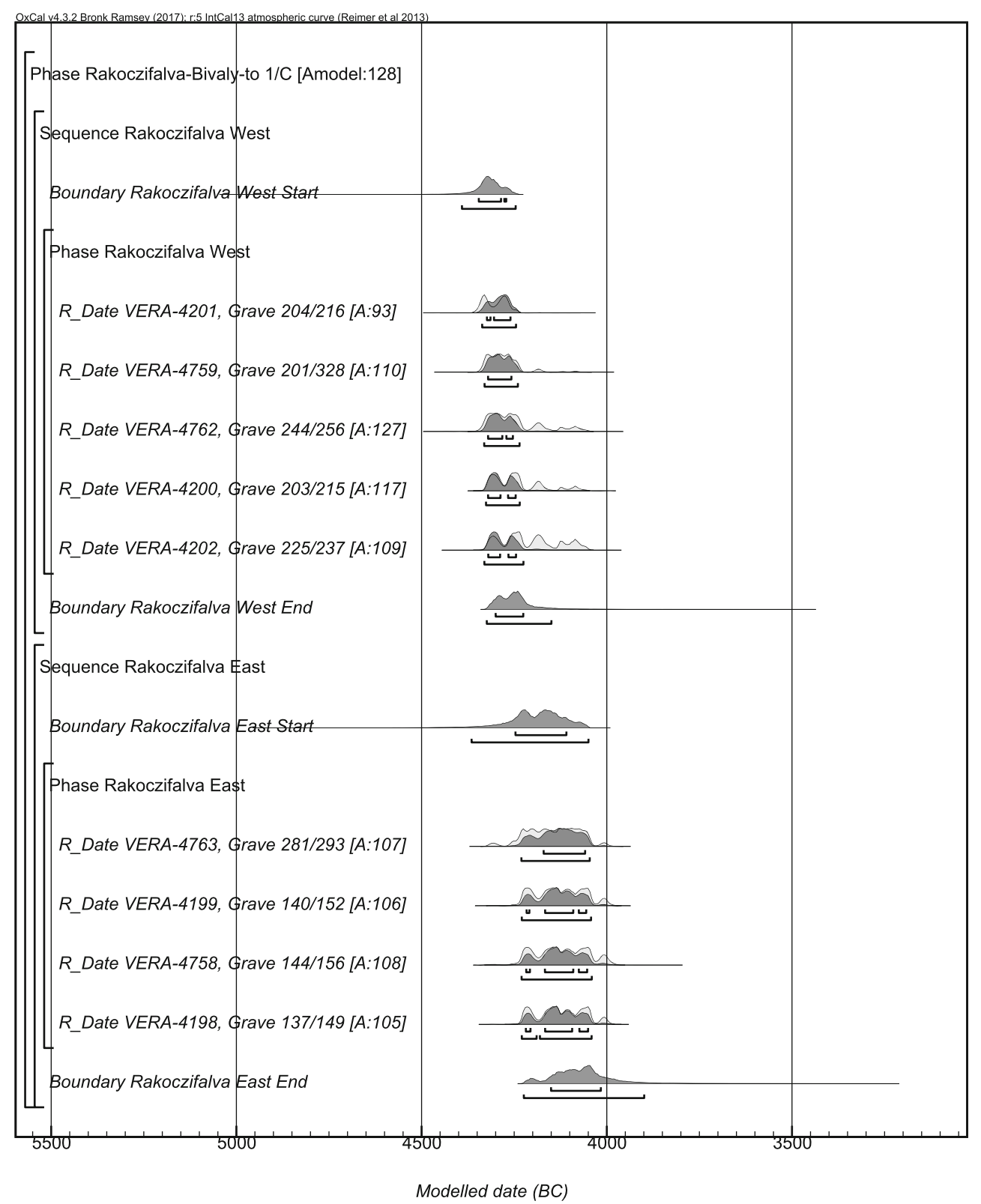

optical emission spectrometer (ICP-OES, TJA IRIS/AP HR) at the laboratory of the Deutsches Bergbau Museum, Bochum. Up to $50 \mathrm{mg}$ of sample material was dissolved in a mixture of hydrochloric and nitric acid. After filling and diluting to a 1000-ppm solution, the elements copper, tin, iron, sulphur, phosphorus and zinc (which are indicators for production technology) and the so-called indicators of origin, arsenic, antimony, nickel, silver and lead, were analysed (Table 1).

The lead isotope abundance was measured by a multicollector thermo-ion mass spectrometer (MC-TIMS, VG Sector 54) at the geochronological laboratory of the Westfälische-Wilhelms Universität, Münster. The isotope ratios were determined after dissolving up to $150 \mathrm{mg}$ of sample material, depending on the lead content and separating the lead by ion exchange in a clean room. Abundance ratios of ${ }^{208} \mathrm{~Pb} /{ }^{206} \mathrm{~Pb},{ }^{207} \mathrm{~Pb} /{ }^{206} \mathrm{~Pb},{ }^{206} \mathrm{~Pb} /{ }^{204} \mathrm{~Pb},{ }^{207} \mathrm{~Pb} /{ }^{204} \mathrm{~Pb}$ and ${ }^{208} \mathrm{~Pb} /{ }^{204} \mathrm{~Pb}$ were analysed (Table 2). Experimental uncertainties for the abundance ratios are $0.1072 \%$ for ${ }^{208} \mathrm{~Pb} /{ }^{206} \mathrm{~Pb}, 0.0716 \%$ for ${ }^{207} \mathrm{~Pb} /{ }^{206} \mathrm{~Pb}, 0.1200 \%$ for ${ }^{206} \mathrm{~Pb} /{ }^{204} \mathrm{~Pb}, 0.1390 \%$ for ${ }^{207} \mathrm{~Pb} /{ }^{204} \mathrm{~Pb}$ and $0.1864 \%$ for ${ }^{208} \mathrm{~Pb} /{ }^{204} \mathrm{~Pb}$. The lead isotope signatures of the artefacts were compared with signatures of ore deposits both in the cases of ${ }^{206} \mathrm{~Pb} /{ }^{204} \mathrm{~Pb}$ vs ${ }^{207} \mathrm{~Pb} /{ }^{204} \mathrm{~Pb}$ and ${ }^{206} \mathrm{~Pb} /{ }^{204} \mathrm{~Pb}$ vs ${ }^{208} \mathrm{~Pb} /{ }^{204} \mathrm{~Pb}$ ratios (Gale et al. 1991, 2000, 2003; Pernicka et al. 1993, 1997; Stos-Gale et al. 1998; Marcoux et al. 2002; Niederschlag et al. 2003; Höppner et al. 2005; Schreiner 2007; Frank and Pernicka 2012; Lutz and Pernicka 2013; Moderrassi-Tehrani and Garner 2014; Artioli et al. 2015, 2016; Pernicka et al. 2016). 


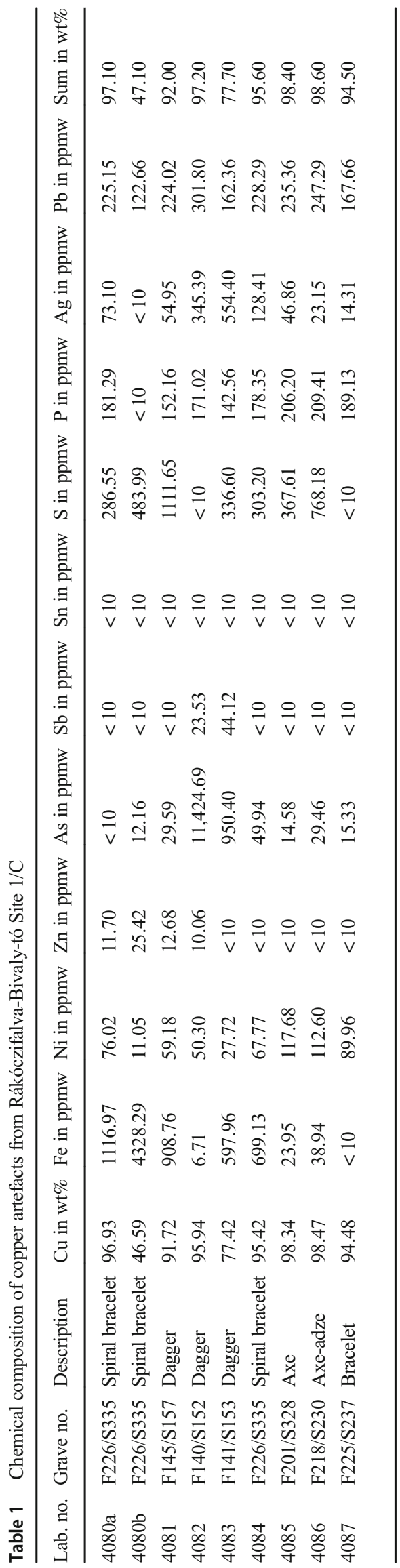

\section{Results}

The chemical composition of copper artefacts was very similar - all of them were made from high-purity copper ore. The impurities usually do not exceed 1 wt. $\%$. Samples $4080 \mathrm{~b}$ and 4083 were strongly corroded. According to their composition, copper finds from Rákóczifalva formed two clusters. The smaller cluster contains two daggers which had higher concentrations of arsenic and silver (Fig. 4).

All of the copper finds which had lead isotope abundance ratios analysed were situated in the western grave group, and they are clearly dated around 4300-4200 cal BC. The lead isotope abundance ratios of two axes are so similar that their raw material could derive from the same source. The lead isotope signatures of the analysed artefacts fitted well with Majdanpek and Central Bulgaria, including Ai Bunar on both graphs (Fig. 5). As the isotopic signatures of these two fields partially overlap, their trace element patterns can distinguish them from one another (Pernicka 2014).

The trace element patterns of analysed objects are very similar. Comparing them with the ores of Majdanpek and Ai Bunar, their lower concentration of arsenic and silver is similar to Majdanpek. The higher concentration of arsenic in two daggers might fit well with Ai Bunar; however, their lead isotope signatures were not examined (cf. data in Pernicka et al. 1993; Radivojević and Grujić 2018).

A large bracelet from the male grave F225/S237 provided an outlier lead isotope ratio, which is not identical to any known raw material source.

\section{Discussion}

The Rákóczifalva site complex provides a unique opportunity to compare the context of the settlement and the cemetery from the point of view of metal finds and metallurgy. A similar incidence of a contemporary settlement and burials, however not entirely excavated, was found in Tiszavalk-Tetes. Szakálhát-type flat axe, pins, a small copper stick and gold pendants were found in the graves (Patay 1978). On the contrary, no metal finds were revealed from settlement features aside from a clay imitation of a gold pendant (Patay 1979).

Comparing the material of the settlement and the cemetery in Rákóczifalva, it seems that the use of metal artefacts had social significance in the ritual context of burials, and they were not necessarily integrated into the life of the settlement. No evidence was found that would support the idea that the members of the Copper Age community living in the neighbouring settlements had the suitable technological knowledge to prepare these items. It seems that these artefacts were rather status or prestige goods which were produced in the Balkans and reached the Great Hungarian Plain as finished products. Therefore, interactions maintained with the Balkan 
Table 2 Lead isotope abundance ratios of copper artefacts from Rákóczifalva-Bivaly-tó Site 1/C. Experimental uncertainties for the abundance ratios are $0.1072 \%$ for ${ }^{208} \mathrm{~Pb} /{ }^{206} \mathrm{~Pb}, 0.0716 \%$ for ${ }^{207} \mathrm{~Pb} /{ }^{206} \mathrm{~Pb}, 0.1200 \%$ for ${ }^{206} \mathrm{~Pb} /{ }^{204} \mathrm{~Pb}, 0.1390 \%$ for ${ }^{207} \mathrm{~Pb} /{ }^{204} \mathrm{~Pb}$ and $0.1864 \%$ for ${ }^{208} \mathrm{~Pb} /{ }^{204} \mathrm{~Pb}$

\begin{tabular}{lllllll}
\hline Lab. nos. & Grave no. & Description & ${ }^{208} \mathrm{~Pb} /{ }^{206} \mathrm{~Pb}$ & ${ }^{207} \mathrm{~Pb} /{ }^{206} \mathrm{~Pb}$ & ${ }^{206} \mathrm{~Pb} /{ }^{204} \mathrm{~Pb}$ & ${ }^{207} \mathrm{~Pb} /{ }^{204} \mathrm{~Pb}$ \\
\hline $4080 \mathrm{~b}$ & F226/S335 & Spiral bracelet & 2.0795 & 0.8424 & 18.560 & 15.635 \\
4085 & F201/S328 & Axe & 2.0800 & 0.8443 & 18.470 & 15.593 \\
4086 & F218/S230 & Axe-adze & 2.0804 & 0.8441 & 18.472 & 15.592 \\
4087 & F225/S237 & Bracelet & 2.1040 & 0.8658 & 17.999 & 15.584 \\
\hline
\end{tabular}

communities must have played an important role in the life of communities on the Great Hungarian Plain, and they must have formed an essential part of their identity. By this time, the use of metal items had a long tradition; therefore, they were neither exotic nor new anymore. Heavy copper tools and golden pendants can be primarily linked to Bodrogkeresztúr-style pottery. The currently available strontium isotope analysis shows that the individuals using the Bodrogkeresztúr style might have been more mobile (Giblin et al. 2013), and they might have had a more significant role in interregional relations. These mobile individuals might have played a crucial role in the spread of metallurgy via the Great Hungarian Plain. As the number of our analysed samples is presently low, we could detect only a relationship with the Balkans but even these results suggest that this community maintained widespread relations with other territories as well.

The Jászladány-type axe which was found in a cenotaph was of the most popular, widespread type, which is frequently found in present-day Serbia, West Bulgaria and the Carpathian Basin (Patay 1984; Vulpe 1975; Todorova 1981; Heeb 2014; Antonović 2014). Siria-type axe is typical in the Carpathian Basin but it is very rare outside this region (Patay 1984; Heeb 2014). Only these two types of axes are known from welldocumented archaeological context from the Early and Middle Copper Age in the Carpathian Basin, and they were always accompanied by Bodrogkeresztúr pottery.

Comparing the chemical composition of the artefactsexcept for the two daggers - from Rákóczifalva with contemporary finds from the Balkans, their composition fits well into chemical cluster 2 in Pernicka et al. (1993). The majority of

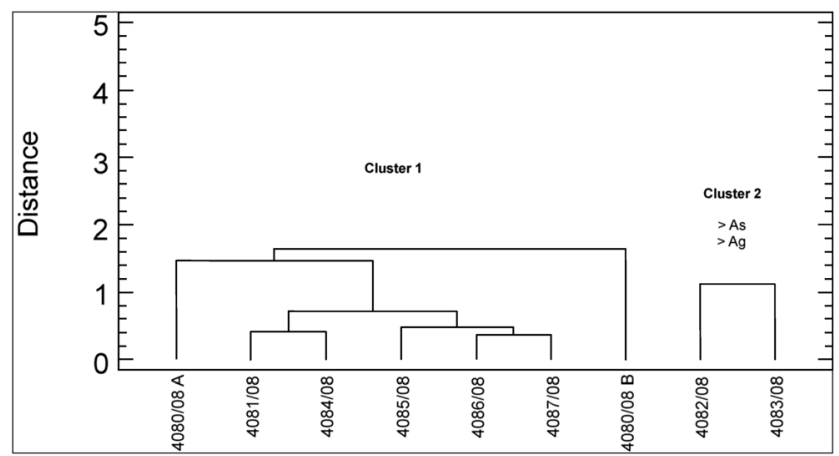

Fig. 4 Average linkage cluster analysis of copper artefacts from Rákóczifalva-Bivaly-tó Site 1/C contemporary finds in Serbia belong to clusters 2 and 3 which can be identical with the ores from Majdanpek (Pernicka et al. 1993). The ores from Majdanpek were frequently used during the Final Chalcolithic in Bulgaria as well (Pernicka et al. 1997). Based on the results of the LIA, the raw material of axes and a spiral bracelet from Rákóczifalva might have originated from the present-day Bulgaria, probably from Ai Bunar, or the present-day Serbia, probably from Majdanpek (Fig. 6).

The composition of daggers fits well with the formerly analysed daggers from the Great Hungarian Plain that were made of pure copper which contained arsenic only as a natural impurity (Vajsov 1993). Daggers with similar composition were also revealed in contemporary sites in Bulgaria and in Slovakia (Schreiner 2007) but no LIA was performed in the latter case.

Various copper artefacts were analysed from several graves in the Durankulak cemetery. In many cases, the lead isotope signatures of copper items from the same grave were significantly different. Thus, varied copper ore deposits might have been available. In several cases, the composition of copper artefacts was also considerably different, which suggests that these objects were not crafted at the same time and probably not even at the same place. On the contrary, there were graves in which both the compositional and lead isotope analyses of artefacts were in good agreement with each other. There is a high probability that these objects were prepared all at once from the same source of metal (Pernicka et al. 1997). A similar conclusion can be drawn in the case of spiral bracelets from the grave F226/S335 at Rákóczifalva as both their trace element patterns and their lead isotope signatures are so similar to each other. Moreover, it is highly likely that these bracelets ended up on the Great Hungarian Plain together.

Although no traces of local metallurgy could be detected in Rákóczifalva or from contemporary settlements on the Great Hungarian Plain, we can find traces of local metallurgy not only in the Balkans but also in the territory of Slovakia and Romania. The beginning of extractive metallurgy was suggested in Handlová and Slovenské Pravno during this period (Schreiner 2007; Moderrassi-Tehrani and Garner 2014). Similarly, some structures at contemporary sites in Romania were interpreted as workshops, and the use of 
Fig. 5 Potential sources of the copper raw material of copper finds from Rákóczifalva-Bivalytó Site $1 / \mathrm{C}$ based on LIA. Bivariate plots show the measured lead isotope ratios, compared with the potential sources (Gale et al. 1991, 2000, 2003; Pernicka et al. 1993, 1997; Stos-Gale et al. 1998; Höppner et al. 2005; Schreiner 2007) according to (a) ${ }^{206} \mathrm{~Pb} /{ }^{204} \mathrm{~Pb}$ vs ${ }^{207} \mathrm{~Pb} /{ }^{204} \mathrm{~Pb}$ and $(\mathrm{b}){ }^{206} \mathrm{~Pb} / 204 \mathrm{~Pb}$ vs ${ }^{208} \mathrm{~Pb} /{ }^{204} \mathrm{~Pb}$
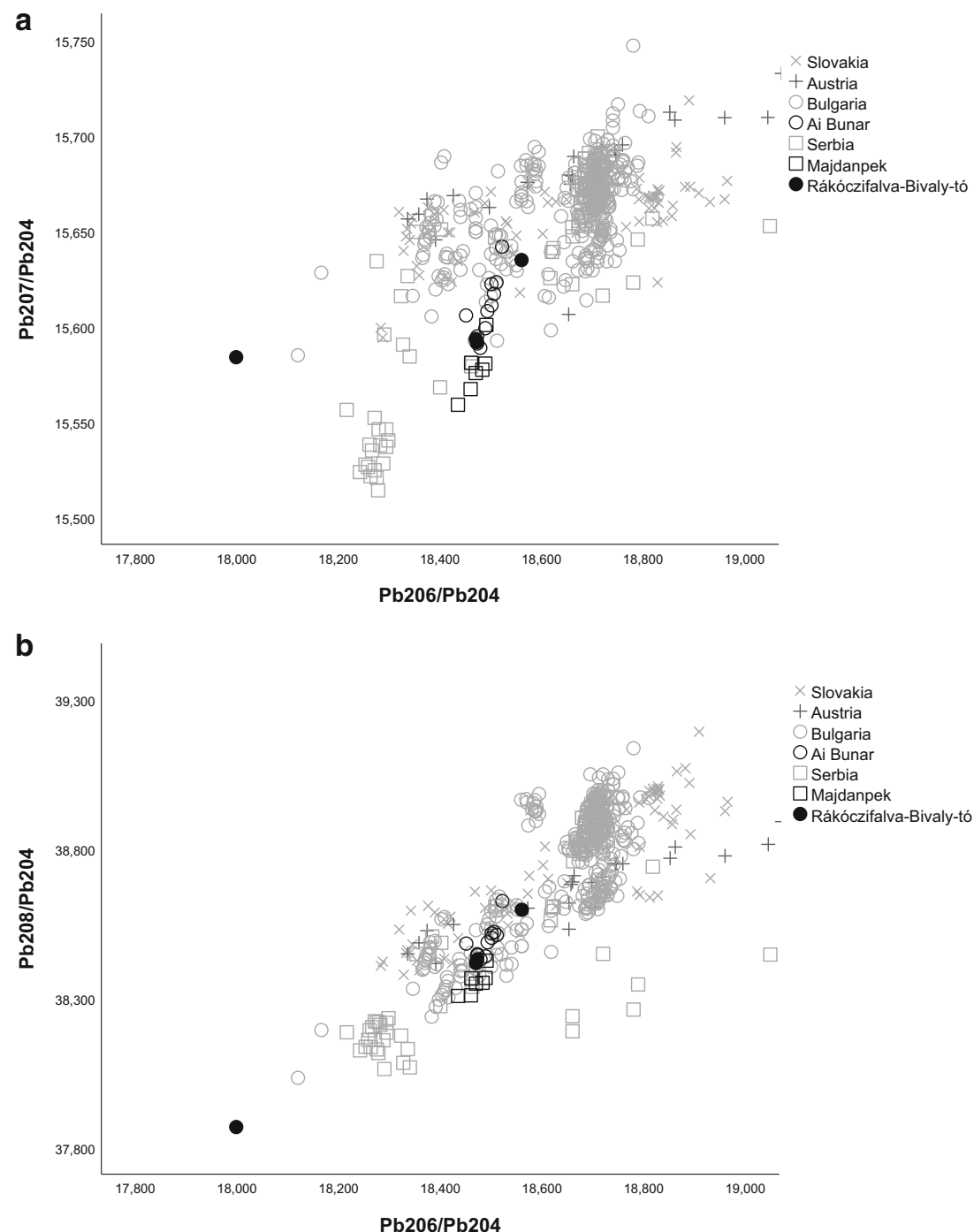

native copper from Transylvania has already been suggested. However, a large series of archaeometallurgical or lead isotope analyses, which would confirm the extraction of Transylvanian sources, are still missing (Kadar 2002; Mareș 2002; Lazarovici 2014).

The extractive metallurgy in the Balkans reached its peak during the Varna and Kodžadermen-Gumelnița-Karanovo (KGK) VI complex which was characterised by a large typological variety and several different production centres (Chernykh 1978b; Todorova 1981; Pernicka et al. 1997). At the end of this period, the metal production also ceased, and it was presumed that the centre of production was relocated to the Central Balkan region (Krivodol-Sălcuța-Bubanj Hum (KSB) with the mine of Majdanpek providing resources), then to the Carpathian Basin (Bodrogkeresztúr). The Central and Eastern Bulgarian copper exploitation system collapsed around $4100 \mathrm{BC}$, and a new one emerged in Eastern Serbia after 4100 BC (Pernicka et al. 1993, 1997). Based on this data, using the methodology of complex network analysis, Radivojević and Grujić interpreted the collapse of copper supply network in Bulgaria and its relocation to Eastern and Central Serbia and later the emergence of Bodrogkeresztúr using the ore deposits in Eastern Serbia during 4100-3700 BC (Radivojević and Grujić 2018).

But according to the new, Bayesian modelled AMS dates, the Bodrogkeresztúr find materials on the Great Hungarian Plain could have been contemporary with the end of KGK VI and with the lifespan of the KSB complex (Raczky and Siklósi 2013; Siklósi and Szilágyi 2016; Tsirtsoni 2016). Therefore, it was a contemporary copper supply network between the Central Balkan and the Carpathian Basin rather than the relocation of the centre of production. The reconstruction of the interregional chronological system is difficult, because a very small amount of AMS data is available from the territory of the KSB complex (cf. Bulatović and Vander Linden 2017). 
Fig. 6 Location of the site and the potential mines from where the raw material of copper artefacts derived

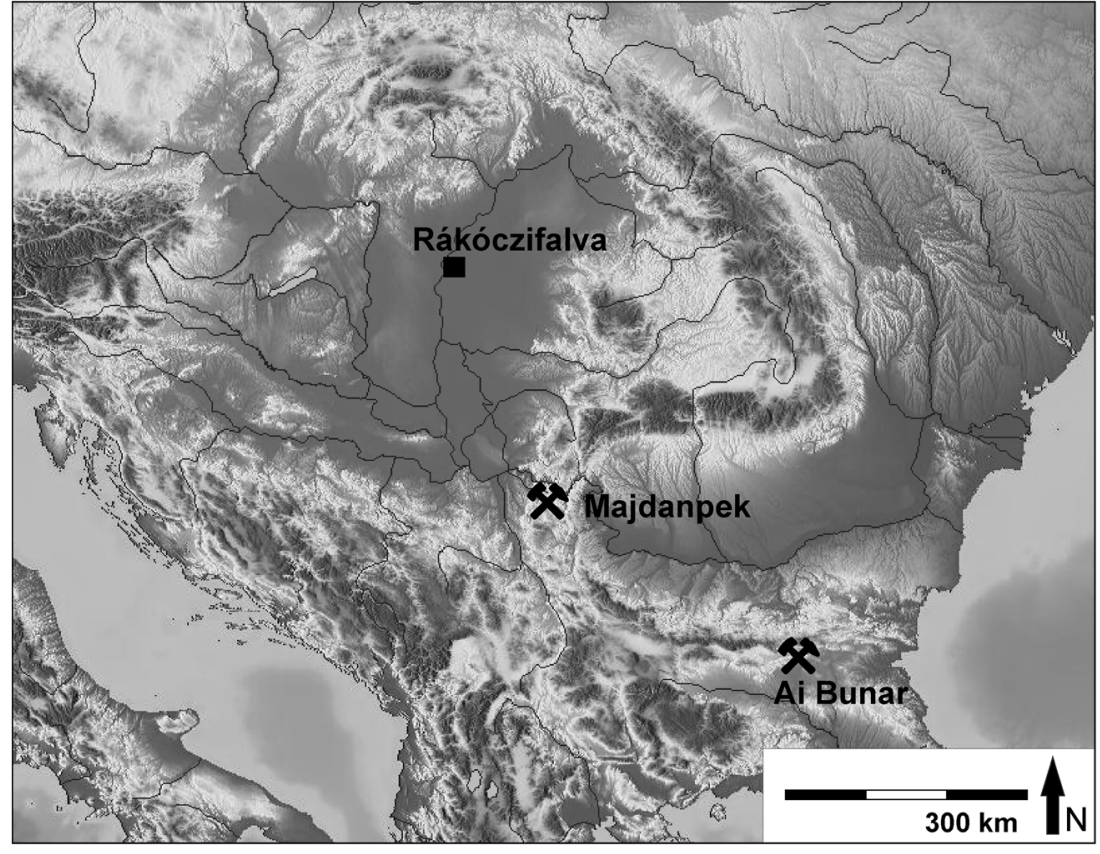

\section{Conclusion}

Returning to the interpretation of the Rákóczifalva site and the Great Hungarian Plain as the core area, it can be suggested that the community living here maintained widespread social interactions with the neighbouring mountainous regions, and their mobile lifestyle facilitated the spread of the metallurgical technology via the Plain, but we cannot see any evidence yet that this territory would have been the centre of metal production in the Copper Age. More correctly, the complex copper supply network of Serbian and Bulgarian extractive metallurgy reached this area as well.

Acknowledgements We are grateful to Dr. Marietta Csányi and Dr. Judit Tárnoki, the archaeologists who conducted the excavations, furthermore to Dr. Pál Raczky who made possible the archaeometallurgical analyses and gave us the permission for evaluating the archaeological material of the site. The archaeometallurgical analyses were conducted by Dr. Michael Prange to whom we hereby express our gratitude. We are also grateful to Tom Dent for proofreading the English text. Grateful thanks to the two anonymous reviewers for their constructive advices.

Funding information Open access funding provided by Eötvös Loránd University (ELTE). Zsuzsanna Siklósi's work was financially supported by the Bolyai János Research Fellowship.

Open Access This article is distributed under the terms of the Creative Commons Attribution 4.0 International License (http:// creativecommons.org/licenses/by/4.0/), which permits unrestricted use, distribution, and reproduction in any medium, provided you give appropriate credit to the original author(s) and the source, provide a link to the Creative Commons license, and indicate if changes were made.

\section{References}

Antonović D (2002) Copper processing in Vinča: new contributions to the thesis about metallurgical character of Vinča culture. Starinar (52):27-45

Antonović D (2014) Kupferzeitliche Äxte und Beile in Serbien. Prähistorische Bronzefunde IX.27. Verlag C.H. Beck, Stuttgart

Antonović D (2016) Alter Kupferbergbau auf dem Balkan. In: Dietz UL, Jockenhövel A (eds) 50 Jahre "Prähistorische Bronzefunde". Bilanz und Perspektiven. Beiträge zum internationalen Kolloquium vom 24. bis 26. September 2014 in Mainz. Prähistorische Bronzefunde XX.14. Franz Steiner Verlag, Stuttgart, pp 33-51

Artioli G, Angelini I, Tecchiati U, Pedrotti A (2015) Eneolithic copper smelting slags in the Eastern Alps: local patterns of metallurgical exploitation in the Copper Age. J Archaeol Sci 63:78-83

Artioli G, Angelini I, Nimis P, Villa IM (2016) A lead-isotope database of copper ores from the Southeastern Alps: a tool for the investigation of prehistoric copper metallurgy. J Archaeol Sci 75:27-39

Bognár-Kutzián I (1963) The Copper Age cemetery of TiszapolgárBasatanya. Archaeologia Hungarica 42. Akadémiai kiadó, Budapest

Bognár-Kutzián I (1972) The Early Copper Age Tiszapolgár culture in the Carpathian Basin. Archaeologia Hungarica 48. Akadémiai kiadó, Budapest

Borić D (2009) Absolute dating of metallurgical innovations in the Vinča culture of the Balkans. In: Kienlin TL, Roberts BW (eds) Metals and Societies. Studies in honour of Barbara S. Ottaway. Universitätsforschungen 169. Verlag Dr. Rudolf Habelt GmbH, Bonn, pp 191-245

Bökönyi S (1988) History of domestic mammals in Central and Eastern Europe. Akadémiai kiadó, Budapest

Bronk Ramsey C (2009) Bayesian analysis of radiocarbon dates. Radiocarbon 51(1):337-360

Bulatović A, Vander Linden M (2017) Absolute dating of Copper and Early Bronze Age levels at the eponymous archaeological site Bubanj (southeastern Serbia). Radiocarbon 59(4):1047-1065 
Chapman J, Tylecote RF (1983) Early copper in the Balkans. Proc Prehist Soc 49:373-376

Chernykh EG (1978a) Aibunar-a copper mine of the fourth millennium BC. Proc Prehist Soc 44:203-217

Chernykh EG (1978b) Gornoe Delo I Metallurgia v Drevneishei Boulgarii. Nauka, Sofia

Comşa E (1991) L'utilisation du cuivre en Roumanie pendant le Néolithique moyen. In: Eluère C, Mohen JP (eds) Découverte du métal. Picard, Paris, pp 77-84

Csányi M, Raczky P, Tárnoki J (2010) Das kupferzeitliche Gräberfeld von Rákóczifalva-Bagi-föld in Ungarn. Altertum 55:241-270

Frank C, Pernicka E (2012) Copper artefacts of the Mondsee group and their possible sources. In: Midgley MS, Sanders J (eds) Lake dwellings after Robert Munro. Proceedings from the Munro International Seminar: The Lake Dwellings of Europe 22nd and 23rd October 2010. University of Edinburgh. Sidestone Press, Leiden, pp 113138

Gale NH, Stos-Gale ZA, Lilov P, Dimitrov M, Todorov T (1991) Recent studies of eneolithic copper ores and artefacts in Bulgaria. In: Eluère C, Mohen JP (eds) La découverte du métal. Picard, Paris, pp 49-75

Gale NH, Stos-Gale Z, Radouncheva A, Ivanov I, Lilov P, Todorov T, Panayotov I (2000) Early metallurgy in Bulgaria. Annuary of Department of Archaeology 4-5:102-168

Gale NH, Stos-Gale Z, Raduncheva A, Panayotov I, Ivanov I, Lilov P, Todorov T (2003) Early metallurgy in Bulgaria. In: Craddock P, Lang $\mathrm{J}$ (eds) Mining and metal production through the ages. The British Museum Press, London, pp 122-173

Giblin JI, Yerkes RW (2016) Diet, dispersal and social differentiation during the Copper Age in eastern Hungary. Antiquity 90(349):8194

Giblin JI, Knudson KJ, Bereczki ZS, Pálfi G, Pap I (2013) Strontium isotope analysis and human mobility during the Neolithic and Copper Age: a case study from the Great Hungarian Plain. J Archaeol Sci 40:227-239

Gyucha A (2015) Prehistoric village social dynamics. The Early Copper Age in the Körös Region. Archaeolingua, Budapest

Heeb J (2014) Copper shaft-hole axes and early metallurgy in southeastern Europe: an integrated approach. Archaeopress, Oxford

Hoekman-Sites HA, Giblin JI (2012) Prehistoric animal use on the Great Hungarian Plain: a synthesis of isotope and residue analysis from the Neolithic and Copper Age. J Anthropol Archaeol 31(4):515-527

Horedt K (1976) Die ältesten neolithischen Kupferfunde Rumäniens. JMV 60:175-181

Höppner B, Bartelheim M, Huijsmans M, Krauss R, Martinek KP, Pernicka E, Schwab R (2005) Prehistoric copper production in the Inn valley (Austria), and the earliest copper in Central Europe. Archaeometry 47(2):293-315

Jansen M (2018) On the use of $\mathrm{Cu}$ isotope signatures in archaeometallurgy: a comment on Powell et al. J Archaeol Sci 93: 211-215

Jovanović B (1971) Metalurgija eneolitskog perioda Jugoslavije. Arheološki institut, Beograd

Jovanović B (1982) Rudna Glava. Najstarije rudarstvo bakra na Centralnom Balkanu. Rudna Glava. Die älteste Kupferbergbau im Zentralbalkan. Muzej rudarstva i metalurgije - Arheološki institut, Bor-Beograd

Jovanović B (1983) Mali Sturac - ein neues prähistorisches Kupferbergwerk in Zentralserbien. Anschnitt 36:177-179

Jovanović B, Ottaway BS (1976) Copper mining and metallurgy in the Vinča group. Antiquity 50:104-113

Junghans S, Sangmeister E, Schröder M (1960) Metallanalysen kupferzeitlicher und frühbronzezeitlicher Bodenfunde aus Europa. Studien zu den Anfängen der Metallurgie 1. Gebr. Mann, Berlin

Junghans S, Sangmeister E, Schröder M (1968) Kupfer und Bronze in der frühen Metallzeit Europas. Die Metallgruppen beim Stand von
12000 Analysen. Studien zu den Anfängen der Metallurgie 2. Gebr. Mann, Berlin

Kadar M (2002) Chemical composition of prehistoric copper artefacts from Transylvania, Romania. Institute for Archaeo-Metallurgical Studies Newsletter 22:11-14

Kalicz N (1992) A legkorábbi fémleletek Délkelet-Európában és a Kárpát-medencében az i.e. 6-5. évezredben. ArchÉrt 119:3-14

Lazarovici G (2014) Beginning of the Copper Age in Transylvania and some data regarding the copper and gold metallurgy. In: Schier W, Draşovean F (eds) The Neolithic and Eneolithic in Southeast Europe. New approaches to dating and cultural dynamics in the 6th to 4th millennium $\mathrm{BC}$. Prähistorische Archäologie in Südosteuropa 28. Verlag Marie Leidorf GmbH, Rahden/Westf., pp 243-271

Lichardus J (1991) Die Kupferzeit als historische Epoche. Versuch einer Deutung. In: Lichardus J (ed) Die Kupferzeit als historische Epoche. Saarbrücker Beiträge zur Altertumskunde 55. Rudolf Habelt Verlag, Bonn, pp 763-800

Lichter C (2001) Untersuchungen zu den Bestattungssitten des südosteuropäischen Neolithikums und Chalkolithikums. Monographien 5. Verlag Philipp von Zabern, Mainz am Rhein

Lutz J, Pernicka E (2013) Prehistoric copper from the Eastern Alps. Archaeometry 1:e25 122-e25 127

Marcoux E, Grancea L, Lululescu M, Milési JP (2002) Lead isotope signatures of epithermal and porphyry-type ore deposits from the Romanian Carpathian Mountains. Mineral Deposita 37:173-184

Mareș I (2002) Metalurgia aramei în neo-eneoliticul României. The metallurgy of copper in the Romanian neo-eneolithic. Editura Bucovina Istorică, Suceava

Meisenheimer M (1989) Das Totenritual, geprägt durch Jenseitsvorstellungen und Gesellschaftsrealität. Theorie des Totenrituals eines kupferzeitlichen Friedhofs zu TiszapolgárBasatanya (Ungarn). British Archaeological Reports International Series 475. BAR, Oxford

Moderrassi-Tehrani D, Garner J (2014) New approaches on mining activities in the Slovakian Ore Mountains. In: Labuda J, Matejková A (eds) Argenti Fodina. Slovenké Banské Múzeum, Banská Štiavnica, pp 45-57

Niederschlag E, Pernicka E, Seifert T, Bartelheim M (2003) The determination of lead isotope ratios by multiple collector ICP-MS: a case study of Early Bronze Age artefacts and their possible relation with ore deposits of the Erzgebirge. Archaeometry 45(1):61-100

Novotná M (1970) Die Äxte und Beile in der Slowakei. Prähistorische Bronzefunde IX/3. C. H. Beck'sche Verlagsbuchhandlung, München

Parkinson WA (2006) The social organization of Early Copper Age tribes on the Great Hungarian Plain. British Archaeological Reports International Series 1573. Archaeopress, Oxford

Patay P (1974) Die hochkupferzeitliche Bodrogkeresztúr-Kultur. BRGK 55:1-71

Patay P (1978) A tiszavalk-tetesi rézkori temető és telep. Kupferzeitliches Gräberfeld und Siedlung von Tiszavalk-Tetes. Folia Archaeol 29: 21-58

Patay P (1979) A Tiszavalk-tetesi rézkori temető és telep. Kupferzeitliches Gräberfeld und Siedlung von Tiszavalk-Tetes. Folia Archaeol 30:27-53

Patay P (1984) Kupferzeitliche Meisel, Beile und Äxte, Ungarn. Prähistorische Bronzefunde IX.15. C. H. Beck'sche Verlagsbuchhandlung, München

Patay P (2005) Kupferzeitliche Siedlung von Tiszalúc. Inventaria Praehistorica Hungariae 11. Magyar Nemzeti Múzeum, Budapest

Patay P, Zimmer K, Szabó Z, Sinay G (1963) Spektrographische und metallographische Untersuchung kupfer- und frühbronzezeitlicher Funde. Acta ArchHung 15:37-64 
Pernicka E (2014) Provenance determination of archaeological metal objects. In: Roberts BW, Thorton CP (eds) Archaeometallurgy in global perspective. Springer, New York, pp 239-268

Pernicka E, Begemann F, Schmitt-Strecker S, Wagner A (1993) Eneolithic and Early Bronze Age copper artefacts from the Balkans and their relation to Serbian copper ores. Praehist Z 68(1): $1-54$

Pernicka E, Begemann F, Schmitt-Strecker S, Todorova H, Kuleff I (1997) Prehistoric copper in Bulgaria: its composition and provenance. Eurasia Antiqua 3:41-180

Pernicka E, Lutz J, Stöllner T (2016) Bronze Age copper produced at Mitterberg, Austria, and its distribution. Arch A 100:19-55

Powell W, Mathur R, Bankoff AH, Mason A, Bulatović A, Filipović V, Godfrey L (2017) Digging deeper: insights into metallurgical transitions in European prehistory through copper isotopes. J Archaeol Sci 88:37-46

Powell W, Mathur R, Bankoff AH, John J, Chvojka O, Tusucká M, Bulatović A, Filipović V (2018) Copper isotopes as a means of determining regional metallurgical practices in European prehistory: a reply to Jansen. J Archaeol Sci 93:216-221

Pulszky F (1884) Die Kupferzeit in Ungarn. A Magyar Tud. Akadémia könyvkiadó hivatala, Budapest

Raczky P, Siklósi ZS (2013) Reconsideration of the Copper Age chronology of the eastern Carpathian Basin: a Bayesian approach. Antiquity 87(336):555-573

Raczky P, Anders A, Siklósi ZS (2014) Trajectories of continuity and change between the Late Neolithic and the Copper Age in Eastern Hungary. In: Schier W, Drașovean F (eds) The Neolithic and Eneolithic in Southeast Europe. New approaches to dating and cultural dynamics in the 6th to 4th millennium BC. Prähistorische Archäologie in Südosteuropa 28. Verlag Marie Leidorf $\mathrm{GmbH}$, Rahden/Westf. pp 319-346

Radivojević M, Grujić J (2018) Community structure of copper supply networks in the prehistoric Balkans: an independent evaluation of the archaeological record from the $7^{\text {th }}$ to the $4^{\text {th }}$ millennium BC. J Complex Netw 6:106-124

Radivojević M, Rehren T, Pernicka E, Šljivar D, Brauns M, Borić D (2010) On the origins of extractive metallurgy: new evidence from Europe. J Archaeol Sci 37:2775-2787

Reimer P, Bard E, Bayliss A, Beck J, Blackwell P, Bronk Ramsey C, Grootes P, Guilderson T, Haflidason H, Hajdas I, Hatté C, Heaton T, Hoffmann D, Hogg A, Hughen K, Kaiser K, Kromer B, Manning S, Niu M, Reimer R, Richards D, Scott E, Southon J, Staff R, Turney C, van der Plicht J (2013) IntCal13 and Marine13 radiocarbon age calibration curves 0-50,000 years cal BP. Radiocarbon 55(4):18691887

Renfrew C (1978) Varna and the social context of early metallurgy. Antiquity 52:199-203

Renfrew C (1986) Varna and the emergence of wealth in prehistoric Europe. In: Appadurai A (ed) The social life of things: commodities in cultural perspective. Cambridge University Press, Cambridge, pp $141-168$

Schier W (2014) The Copper Age in Southeast Europe - historical epoch or typo-chronological construct? In: Schier W, Draşovean F (eds) The Neolithic and Eneolithic in Southeast Europe. New approaches to dating and cultural dynamics in the 6th to 4th millennium BC. Prähistorische Archäologie in Südosteuropa 28. Verlag Marie Leidorf GmbH, Rahden/Westf. pp 419-435

Schreiner M (2007) Erzlagerstätten im Hrontal, Slowakei. Genese und prähistorische Nutzung. Forschungen zur Archäometrie und Altertumswissenschaft 3. Verlag Marie Leidorf GmbH, Rahden/ Westf
Sherratt A (1983) The development of Neolithic and Copper Age settlement in the Great Hungarian Plain, part II: site survey and settlement dynamics. Oxf J Archaeol 2(1):13-41

Sherratt A (1984) Social evolution in Europe in the later Neolithic and Copper Age. In: Bintliff J (ed) European Social Evolution. University of Bradford, Bradford, pp 123-134

Siklósi ZS, Prange M, Kalicz N, Raczky P (2015) New data on the provenance of Early Copper finds from the Great Hungarian Plain. In: Hansen S, Raczky P, Anders A, Reingruber A (eds) Neolithic and Copper Age between the Carpathians and the Aegean Sea. Chronologies and Technologies from the 6th to the 4th Millennium BCE. International Workshop Budapest 2012. Archäologie in Eurasien 31. Habelt-Verlag, Bonn, pp 57-92

Siklósi ZS, Szilágyi M (2016) Módszertani, interpretációs kérdések az alföldi rézkor radiokarbon keltezése kapcsán. Questions on methodology and interpretation concerning the radiocarbon dating of the Copper Age on the Great Hungarian Plain. Tisicum 25:65-72

Šiska S (1964) Pohrebisko tiszapolgárskej kultúry v Tibave. SlA 12/2: 293-356

Šljivar D (1996) The eastern settlement of the Vinča culture at Pločnik: a relationship of its stratigraphy to the hoards of copper objects. Starinar 47:85-97

Šljivar D (2006) The earliest copper metallurgy in the central Balkans. Metalurgija 12/2-3:93-104

Šljivar D, Kuzmanović-Cvetković J, Jacanović D (2006) BelovodePločnik, new contributions regarding the copper metallurgy in the Vinča culture. In: Tasić N, Grozdanov C (eds) Homage to Milutin Garašanin. Serbian Academy of Sciences and Arts, Belgrade, pp 251-266

Sofaer Derevenski J (1997) Age and gender at the site of TiszapolgárBasatanya, Hungary. Antiquity 71:875-889

Stos-Gale ZA, Gale NH, Annetts N, Todorov T, Lilov P, Raduncheva A, Panaytov I (1998) Lead isotope data from the Isotrace Laboratory, Oxford: Archaeometry database 5, ores from Bulgaria. Archaeometry 40/1:217-226

Strahm C, Hauptmann A (2009) The metallurgical developmental phases in the Old World. In: Kienlin T, Roberts B (eds) Metals and Societies. Studies in honour of Barbara S. Ottaway. Universitätsforschungen zur prähistorischen Archäologie 169. Verlag Dr. Rudolf Habelt GmbH, Bonn, pp 116-128

Szilágyi M (2015) Kora rézkori településszerkezet a Közép-Tiszavidéken. Unpublished $\mathrm{PhD}$ dissertation. Eötvös Loránd University, Budapest. https://edit.elte.hu/xmlui/handle/10831/30002. Accessed 21 September 2018

Todorova H (1981) Die kupferzeitliche Äxte und Beile in Bulgarien. Prähistorische Bronzefunde IX.14. C. H. Beck'sche Verlagsbuchhandlung, München

Tsirtsoni Z (ed) (2016) The human face of radiocarbon: reassessing chronology in prehistoric Greece and Bulgaria, 5000-3000 cal BC. Travaux de la maison de l'Orient et de la Méditerranée $\mathrm{N}^{\circ} 69$. Maison de l'Orient et de la Méditerranée, Lyon

Vajsov I (1993) Die frühesten Metalldolche Südost- und Mitteleuropas. Praehist Z 68(1):103-145

Vizdal J (1977) Tiszapolgárske pohrebisko vo Vel'kých Raškovciach. Vydalo Východoslovenské vydavatel'stvo, Košice

Vulpe A (1975) Die Äxte und Beile in Rumänien II. Prähistorische Bronzefunde IX/5. C. H. Beck'sche Verlagsbuchhandlung, München

Publisher's note Springer Nature remains neutral with regard to jurisdictional claims in published maps and institutional affiliations. 